\title{
TOWARDS MAKING OPTIMAL DECISIONS IN THE SERBIAN ARMY FOR REDUCING THE EFFECTS OF ORDNANCE EXPLOSIONS
}

\author{
Dejan S. Stojanovića ${ }^{a}$ Petar Lj. Stojilkovićb \\ a Serbian Armed Forces, 4th brigade of Land Forces, Vranje, \\ Republic of Serbia, \\ e-mail: dejans44@yahoo.com, \\ ORCID iD: (Dhttp://orcid.org/0000-0001-6220-5990 \\ b Institute for Safety and Health at Work and Fire Protection, VIP Center \\ Ltd., Leskovac, Republic of Serbia, \\ e-mail: vip.agencija@yahoo.com, \\ ORCID iD: Dhttp://orcid.org/0000-0001-8290-924X
}

DOI: $10.5937 /$ vojtehg65-10514

FIELD: Environmental Protection and Crisis Management ARTICLE TYPE: Professional Paper ARTICLE LANGUAGE: English

Abstract:

The paper proposes organising a professional team of the Serbian Army members who would, in addition to their regular duties, assess the hazards, risk and threats of possible explosions of explosive materials and suggest accordingly optimal decsions to decision makers. Operational meetings are defined, followed by the explanation of the importance of training a team of experts for making optimal decisions, in order to reduce the security threat to people and property from the effects of the explosion of explosive materials. The research results and the discussion point to the lack of involvement of other members of the Serbian Army in the basic command functions when proposing solutions for making optimal decisions. It has been emphasized that the findings of the research process would increase the security and safety of all members of the Serbian Army from the effects of explosions of explosive materials.

Key words: optimal decision, ordnance, explosion. 


\section{Introduction}

By making optimal decisions, Serbian Army members tend to prevent any occurrence of adverse events during explosions of explosive materials with disastrous results. If it is known that the basic characteristic of all ordnance is the release of large amounts of energy due to chemical decomposition resulting in mechanical work on the environment and destroying all living beings, then a timely decision represents the basis for a timely neutralisation of all possible sources of security threats to people and property from the occurrence of ordnance explosions ${ }^{1}$.

The chemical process of decomposition of explosives and explosive materials at the expense of oxidation of carbon and hydrogen with oxygen from the structure of specific molecule groups causes a break of energyrich bonds at variable speed ${ }^{2}$, when heat energy is released with a creation of large amounts of gases. The expansion of these gaseous products due to very high pressure causes lethal and destructive effects of explosions. It is this property of explosive compounds which has the explosive effect on the surroundings, thus endangering the safety of people and their property.

The chemical process of explosive decomposition of explosive compounds is a characteristic feature of explosive materials; it occurs at speeds ranging from a few $\mathrm{cm} / \mathrm{s}$ to several $\mathrm{km} / \mathrm{s}$. A slow reaction of an explosive compound ${ }^{3}$ does not pose a major threat or risk to the safety of people and property, while relatively fast decomposition reactions of explosive compounds $(9.5 \mathrm{~km} / \mathrm{s}$ for a detonation) with the release of large amounts of thermal energy and the creation of high-pressure gases pose a great threat to people and their property. The faster the decomposition of explosive devices, the stronger the explosive, which therefore puts people and property at higher risk and greater danger (Stojanović, 2013, p.11).

\footnotetext{
1 Explosive materials consist of the smallest particles (molecules and atoms) which build a composite explosive substance and carry basic properties of these materials (substances). How much energy will be released by the chemical decomposition of explosive compounds, primarily depends on their chemical composition which consists of $\mathrm{C}, \mathrm{H}, \mathrm{O}$ and $\mathrm{N}$ atoms, with the addition of certain additives, bound by single, double, triple and larger chemical bonds, such as: $\mathrm{C}-\mathrm{NO}_{2} ; \mathrm{CO}-\mathrm{NO}_{2}$ and $\mathrm{N}-\mathrm{NO}_{2} ;-\mathrm{N}=\mathrm{N}-$ Thus interconnected atoms within structural molecule groups build complex explosive compounds of high energy potential.

2 Chemical reaction rate is the combustion distance per unit of time.

3 Relatively slow decomposition reactions of explosive compounds are typical mainly for gunpowder and rocket fuel, the explosive decomposition energy of which is used to launch missiles and rockets in gun barrels.
} 
In these circumstances, negative effects either occur suddenly and unexpectedly or they start slowly but gradually assume stronger forms. Bearing in mind the above given forms of dangers, risks and threats, members of the Serbian Army need to prevent any form of uncontrolled explosions by making optimal decisions for reducing the effects of explosions of explosive materials.

\section{Creating a team of experts}

Explosions of explosive materials can happen at any time and in places where explosive materials are produced, stored and maintained (military industry for ordnance production, field and stationary warehouses, etc.) as well as in places where large amounts of explosive materials are used for efficient and effective exercises with live ammunition (shooting ranges and training grounds for training and checking the level of military personnel's acquired knowledge and skills and their competence to carry out combat operations). This is why those in charge have to make decisions about which dangers, risks and threats from the occurence of explosions of explosive materials need to be considered at workplaces ${ }^{4}$ and the working environment ${ }^{5}$ and to which extent. In order to make optimal decisions, it is necessary to form teams of experts at the army unit level, who will, along with their regular duties, assess the danger, risk and threat of the occurence of explosive material explosions. They will also suggest types of development of possible unexpected events.

The organizational structure of expert teams at the level of a battaliondivision would consist of: unit commander ${ }^{6}$, deputy commander, resource protection officer, chief of the logistics group and subordinate commanders who are from these units (Figure 1).

4 Workplace is a space for performing job duties (inside or outdoors, as well as on combat equipment) where one performs one's duties or is allowed to access during work (Službeni vojni list, 2014).

${ }^{5}$ Working environment is the area where work and training are carried out, including also workplaces, working conditions, working procedures and relations during work and training processes (Službeni vojni list, 2014).

6 The unit commander is responsible for the production, storage and maintenance of explosives, as well as for the unit carrying out exercises with live ammunition. 


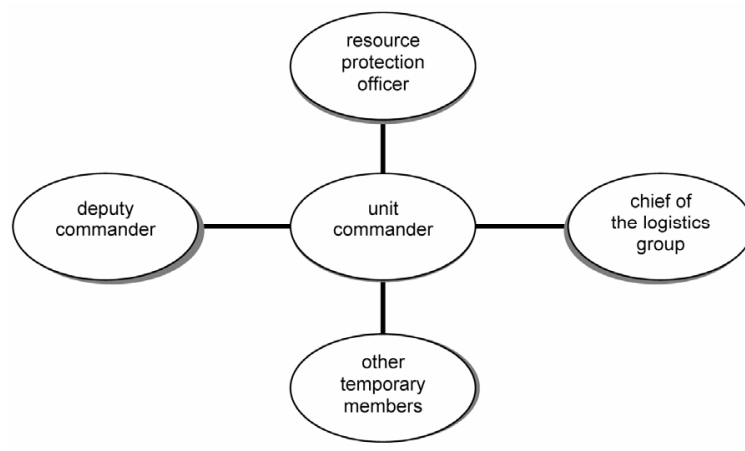

Figure 1 - Organizational structure of the expert team of a battalion-division Puc. 1 - Организационная структура экспертной группы батальона-дивизиона Слика 1 - Организацијска структура стручног тима батаљона - дивизиона

Since all the members of expert teams already have their assigned duties depending on their positions in the army, it is necessary to allocate their responsibilities when assessing dangers, risks and threats of the occurrence of explosions of explosive materials. Their responsibilities will be more precise and clearer if regulated by law and if duties (responsibilities) are defined for each member in particular.

The organizational structure in the Serbian Army is centralized. The commander with the already existing command represents the highest decision-making level. The commander commands subordinate units and is responsible for all the aspects of further managing dangers, risks and threats (Karović, Komazec, 2010, p.230). When performing an activity, the commander is in charge of making a decison which represents one of the versions of his mental work to ensure safe execution of tasks. This decision is a concept (knowledge and skill) or the final result of the mental work concerning the execution of a given task in an optimal manner. After consulting the other members of a temporary unit for making optimal decisions, the commander makes the final decision to perform the given tasks as a result of the assessment of all the elements of the situation and variants of the action. Thus begins the safe execution of the task because the commander is held responsible for the safety of all the members of the unit and their protection from all possible sudden events in which effects of the explosion of explosive materials can occur. When unexpected events do occur, problems usually pile up and many wrong decisions are made. This is why heavy responsibility lies on the commander who needs to quickly analyze the causes, assess the consequences and take concrete and constructive measures to overcome the current situation. It is necessary to include the deputy commander in helping the unit commander to avoid certain problems. The main role of the deputy 
commander would be to coordinate and organize meetings, provide proper working conditions, inform the members of the expert team about the requirements of the superior command and about the events from the previous period, to monitor the results, to inform the commander about the achieved goals and to substitute the commander when the commander is unable to attend meetings.

In the process prior to the final decision making, it is necessary to consult the resource protection officer and the chief of the logistics group before each activity.

The role of the resource protection officer would be to assess a possible threat to the Serbian Army members from the effects of an explosion of explosive materials, inform the other expert team members about the dangers, risks and threats of the explosion(s) of explosive materials which threaten to endanger the safety of people and property in a particular area as well as about the dangers, risks and threats that occurred in the previous period. The chief of the logistics group should inform the other team members about the storage of the explosives which would be used in practice or stored in the warehouse, about their amounts, sensitivity, instability as well as about a possibility of explosions of explosive materials during their transport, storage or maintenance.

It must be noted that the command led by the commander is in charge of decision making and introducing certain measures of protection and the course of actions to mitigate and eliminate safety threats to the security of people and their property from the effects of explosions. All these measures are to be undertaken before a sudden event occurs. In order to have everything executed in an organised and planned manner, the commanding staff in the Serbian Army are trained to successfully make decisions concerning assessment of current danger conditions, risks and threats that could occur in case of ordnance explosions. The essence of making optimal decisions stems from the relation of subordination, i.e. all orders come from the command (the managing part of the institution). For the safe, successful and efficient functioning of the command in critical situations, when there is not much time for dispute and discussion, it is necessary to include other members of the commanding staff and commanders of basic units into the organizational structure of expert teams, depending on the commander's opinion and assessment. They would attend operational meetings where all potential causes of explosions of explosive materials would be discussed within a certain timeframe. 


\section{Operational meetings of expert teams}

It is necessary to organize operational meetings with the members of expert teams for making optimal decisions in order to discuss the current safety conditions of army members concerning the effects of ordnance explosions and in order to avoid critical events. These meetings should be transparent and open for suggestions and discussions and all the additional explanations. All team members should be able to give their opinions in order to establish a positive atmosphere within the team. It is of special importance that the experience from the previous period be communicated among them so that decisions could be made based on judgement (experience based) ${ }^{7}$ in order to avoid similar events which could escalate in the future. This shows that, at a certain point, people and property were threatened by possible ordnance explosions, so, in order to avoid such events in the future, it is necessary to discuss the matter and try to find solutions for the same or similar situations.

Example: During a live firing exercise of an artillery unit, the cases containing HE shells ${ }^{8}$ with the overhauled UTIU $M-72^{9}$ impact initially delayed action fuze were used for the exercise (Rule on the $122 \mathrm{~mm}$ selfpropelled howitzer). For this type of projectiles, there are special firing tables which happened to be left behind and not taken for this particular firing exercise. In this situation, the commander must decide whether to continue practice and perform firing with overhauled projectiles, or to stop the exercise thus reducing the danger, risk and threat of a possible occurrence of the effects of an ordnance explosion. This experience may help in the future in dealing with concerns about many problems that may arise before performing exercises with live ammunition and it can also help subordinate units to determine which equipment they must have to successfully perform the shooting.

During operational meetings, while temporary members of expert teams talk about their experience in the situations in which they were exposed to certain dangers, risks and threats of possible ordnance

\footnotetext{
7 Making decisions based on judgment involves repeating a situation or unconsciously linking different situations and connecting them with the current one.

8 An he shell is designed to destroy and neutralize living force and weapons sheltered or not, to destroy and neutralize mortars, artillery and missile weapons, as well as to provide fire support to infantry, motorized and armored units in anti-tank warfare. An HE shell consists of the casing, the explosive charge, the driving band, the primer, propelling charge and the cartridge (Rule on the 122 $\mathrm{mm}$ self-propelled howitzer).

9 The UTIU M - 72 fuze type is upper, impact, with quick, inertial or delay action with the broken initial chain, and can be adjusted to quick (o) or delayed (z) action (Rule on the $122 \mathrm{~mm}$ self-propelled howitzer).
} 
explosions and about the solutions for overcoming such situations, the deputy commander gathers all the suggestions and facts in a form suitable for a rational and constructive decision-making process ${ }^{10}$. Commanders can propose solutions in these meetings; they are interested in the opinion of each member, so they need to be present there and stimulate mutual understanding and finding the solution by participating and asking questions, since all the aspects of possible events are taken into concideration. Commanders' actions are instantaneous, visible and distinctive and they set an example to those expecting his decision. This is where it can be seen how competent a commander is, how he handles dangerous situations when threatened by the risk of ordnance explosions. The commander is responsible for decision making in line with his responsibilities. Making these decisions by analyzing the danger, risks and threats prevents possible events from occurring, since autonomous decision making in a short period of time carries in itself certain danger, risk and threat. Any unauthorized action is exceeding one's authority, and the use of authority outside security objectives is an abuse of power; in such cases, the security of the object of protection is endangered (Mijalkovski, Đorđević, 2010, p.290).

An analysis of hazards, risks and threats is always associated with adverse outcomes and consequences that occur in the near future. Commanders analyze all the circumstances that may affect the likelihood ${ }^{11}$ of re-occurrence of adverse events from the past (Karović, Komazec, 2010, p.232). The assessment of the probability of occurence of adverse events predicts new events that can be caused by the effects of ordnance explosions in the future, based on available information. Decision alternatives can be then evaluated and a logical framework prepared for the commander, thus creating choices in decision making and reducing uncertainty in critical situations. Events from the previous period have shown that good commanders are open, positive and flexible in critical situations as well as decisive and quick decision-makers when necessary. In any case, it is better to make any decision on a tactical level, than to indefinitely postpone the decision making process. Every decision has to be made in the general interest of the Serbian Army, since decision making is inseparable from the responsibility of decision-makers. Tactical decisions are made by commanders of divisions and battalions at the

${ }^{10}$ Rational decision making means having all important facts and information needed for decision making.

11 The classic definition of probability was based on an intuitive and experiential notion of probability of events as a relative frequency of a number of favorable outcomes and on the generalization of this notion (http://starisajt.elfak.ni.ac.rs/phptest/new/html/Studije/predavanja-literatura/matematikaodabrana-poglavlja/verovatnoca.pdf). 
lowest decision-making levels, which provides the basis for the implementation of duties and changes initiated at higher (operational or strategic) levels of decision making.

Deciding on dealing with (solving) security challenges represents the highest level of exposure of the decision-maker to hazards, risks and threats (Mijalkovski, Đorđević, 2010, p.302). In this segment, the commander, in line with his delegated right of decision making, opts for the best variant of intuitive decision making ${ }^{12}$, taking into account fully or partially (or not al all) the proposals of expert team members on resolving defined hazards, risks and threats. The chosen variant may contain danger, risk and threat. It can be very successful in dealing with the threat to the security of people and property in case of ordnance explosions, but it can also result in serious, adverse consequences. It can be chosen based on an unconscious or wrong assessment of the situation that can end in a fiasco.

It is, therefore, recommended that the Regulations on Safety and Health at Work at the Ministry of Defence and the Serbian Army engage some of independent licensed organizations that can help in assessing situations and provide services in the field of safety and health at work ${ }^{13}$ in the following situations:

- when there are no experts on safety and health at work within a given system,

- when there is a need for an independent assessment of situations in which tactical exercises with live firing are conducted,

- when there is a training of units and services within one or both branches of the Serbian Army ${ }^{14}$ (Službeni glasnik Republike Srbije, 88/2009).

The participation of outside organizations is necessary in special cases of assessment of dangers, risks and threats, and for special, modern support systems (hardware and software support). A complex decision-making process is not possible without appropriate information support. Such a support system was developed in the mid-eighties when

\footnotetext{
${ }^{12}$ Intuitive decision making is when there are not enough facts and information and when it is not possible to explain the decision that was made as a result of considering several proposals-variants, but the decision-maker makes the decision based on his/her feeling (https://prezi.com/llc4qg94zrzj/ intuitivno-odlucivanje/).

${ }^{13}$ By risk assessing, the Institute of Safety and Health at Work and Fire Protection can determine the first level of preventive measures which is essentially related to the review of all aspects of work, and is conducted in order to identify elements that can cause injury or damage, remove the dangers and introduce preventive or protective measures to control the risk and create conditions for risk management.

${ }^{14}$ The Serbian Army consists of: Armed Forces, Air Force and Air Defence (Zakon o Vojsci Srbije, 2007).
} 
computer technology was developed, contributing to decision making automation, thanks to Information-Communication support. Involvement of independent licensed organizations in industries for production of explosive materials is also recommended for easier evaluation of the security risk to people and property from the effects of explosions of explosives. The participation of outside organizations would have its limitations and would be regulated by the contract of the command, proposed by the expert team.

The command organisation depends on adverse events and suggestions of expert teams on reducing the security risk to people and property from the effects of ordnance explosions.

\section{Expert team training}

Training members of expert teams to make optimal decisions is of importance for decision making in critical situations. in order to facilitate for team members to understand their roles and responsibilities, it is necessary for them to occasionally meet and discuss issues related to increasing safety of people and property in case of explosions of explosive materials. This would facilitate their work in situations when there is a need for maintaining a high level of awareness and responsibility when proposing solutions to the commander concerning the assessment of situations and making optimal decisions. This would be a unique opportunity to ask questions to the person in charge of decision making and to start a discussion about all issues referring to possible explosions of explosive materials.

Based on the comprehensive retrospective of the sudden events of ordnance explosions which occurred in the past, the resource protection officer informs expert team members about such events. In this process, discussions about possible similar occurrences in the future and procedures in making decisions in critical situations are of great significance. After getting acquainted with the facts, expert team members discuss and predict possible directions of adverse events caused by ordnance explosions, applying a logical-formal analysis based on problem solving with a formalized sequence. The mitigation of hazards, risks and threats of the occurrence of the effects of ordnance explosions is conducted in the following situations:

- if the activity which was estimated as the one that could lead to the appearance of the effects of the explosion of explosive materals had not been started. 
- if the activity is subconciously or consciously postponed,

- when the activity is disrupted because of excessive physical or psychological stress,

- when the activities are divided into several partial ones which can be controlled better,

- when the activities are transferred from one person to another or from a person to an organization,

- when preventive actions are taken in order to reduce the frequency or severity of consequences in order to affect every possibility of ordnance explosion in a workplace or in a working environment. (Stojanović, Stojilković, 2016, p.1068).

When applying a method for reducing the level of threat to the safety of people and property in case of explosions of explosive materials, many different solutions are proposed, so that there are no wrong solutions in the end. Having participated in the analysis during the decision-making process, team members suggest the decision-maker how to overcome certain critical phases. The decision-maker should accept their proposals without much criticism and dispute in order to successfully overcome possible critical phases. The cohesion of the expert team is thus created and a two-way communication flow is established between the members who do the analysis and the decision-maker. These members propose the solutions while the decision-maker makes constructive decisions. This contributes to the development of creative thinking of individual team members, which will enable them to cope more easily with different situations. This way, the decision making process is focused on predicting alternative worst case scenarios so that an optimal decision could be made in order to avoid problems before they occur.

The decision-making process ${ }^{15}$ takes place in high-risk situations with a high level of uncertainty, which represents a challenge for the highest level of command (the commander with the already existing command who commands, manages and is responsible for everything that happens in the commanding unit) to understand the surroundings on the macro and micro level and to provide protection to all Serbian Amy members, thus achieving the set goals of working safely (Mijalkovski, Đorđević, 2010, p.303). Unfortunatelly, events from the past show that nothing is easily predictable. In some sudden events, it is not possible to completely predict dangers, risks and threats of explosions of explosive materials ('There are

\footnotetext{
${ }^{15}$ The process of decision making is a dynamic process the aim of which is to have the best course of action of the resource management system for a particular situation or to achieve the desired conditions of the system.
} 
1,000 reasons AGAINST, and only a few FOR, so if something can go wrong, it will go wrong!' - Murphy), which can lead to human casualties, loss of material resources and financial losses. However, if operational meetings are held regularly and Serbian Army members are regularly educated, there is a strong possibility of avoiding the occurence of adverse events with disastrous outcomes. In order to bring possible dangers, risks and threats to a minimum, it is necessary to enable the commanders to successfully assess the existing conditions in order to make timely decisions in critical situations and avoid the wrong assessment, which often happens during wartime. A wrong decision would mean that the commander did not apply his military expertise and professionalism in the best way. Wrong assessments could appear on different levels of command, and the only way to avoid them is by consulting expert team members. Consultations with team members enable the commander to solve problems more easily. They also help the commander to monitor the development of risky situations, to understand them correctly and react properly. The most important is that the commander has a timely reaction in the decision-making process, which makes him/her active when such a reaction is expected. Consultations represent the relationship between the commander, who needs advice or some help in making decions, and the expert team who make optimal decisions for reducing the effects of the explosions of explosive materials. Regular consultations improve professional, logical and critical thinking, which contributes to finding constructive and safety solutions during the process of realization of given tasks.

\section{Results of the research and the discussion}

A large number of research works are dedicated to increasing the quality of work and life of the Serbian Army members, while the safety of people and property from explosions of explosive materials in this sphere is insufficiently explored. This is why the issue of increasing the safety of people and property in case of explosions was excluded from the fundamental commanding functions during the process of reorganization of the Serbian Army and its adaptation to the international framework and to the needs for preservation of independence, territorial integrity and sovereignty of the country from armed threats as well as to the needs for protecting national security. The need for improving this field comes from the idea that predicting events from possible explosions of explosive materials with uncertain outcomes should become a part of regular activities. It is each commander's obligation to keep the operational and functional capability of units on a high level even in situations 
with potential danger, risk and threats from adverse events with disastrous outcomes. Managing such uncertainties which bring a certain level of danger, risk and threat from explosions of explosive materials makes the commanding system more responsible. This is why commander's responsibilty represents an obligation or the ability to make optimal decisions, regardless of the control hierarchy in the chain of command. It also represents the commander's ability to distinguish what is safe and useful from what causes the effects of ordnance explosions. The commander has a responsibility to inform the superior officer but also to fulfil the expactations of the subordinate officer concerning the decision made. The purpose of this is to create the atmosphere of trust in the commanding system and show that people are taken care of.

To gain an insight into the process of decision making of the command, members of the Serbian Army were given an anonymous survey online (https://docs.google.com/forms/d/14vXWfr7LOtfcjerRpzttwB4y84M52eb814vAWs 1 Ap70/viewform). The aim of the survey was to eastablish to what extent subordinate units trust the command and believe that there will be no safety threats to people and property from explosions of explosive materials. The survey was based on the collected data on the views and opinions of the respondents to the survey (Table 1).

Table 1 - Trust of the subordinates in the command system

Таблица 1 - Доверие подчиненных в системе командования

Табела 1 - Поверење потчињених у систем командовања

\begin{tabular}{|l|l|c|c|c|}
\hline No. & $\begin{array}{l}\text { To what extent are the survey questions present in the } \\
\text { respondent's workplace? }\end{array}$ & Yes & No & $\begin{array}{c}\text { No } \\
\text { opinion }\end{array}$ \\
\hline 1. & $\begin{array}{l}\text { Have the decisions of superiors met your expectations that } \\
\text { explosions of explosive materials will not occur? }\end{array}$ & 36 & 23 & 5 \\
\hline 2. & $\begin{array}{l}\text { Do you believe that the command system will increase the } \\
\text { safety concerning the occurence of ordnance explosions? }\end{array}$ & 40 & 14 & 10 \\
\hline 3. & $\begin{array}{l}\text { Are the decisions of superiors quick and efficient in } \\
\text { situations where there is danger, risk and threat of } \\
\text { explosions of explosive materials? }\end{array}$ & 38 & 17 & 9 \\
\hline 4. & $\begin{array}{l}\text { Is the superior responsible for the decisions in situations } \\
\text { where there is danger, risk and threat of explosions of } \\
\text { explosive materials? }\end{array}$ & 49 & 10 & 5 \\
\hline 5. & $\begin{array}{l}\text { Does the superior maintain operational and functional } \\
\text { capability of the unit when there is potential danger,risk } \\
\text { and threat from explosions of explosive materials? }\end{array}$ & 39 & 10 & 15 \\
\hline 6. & $\begin{array}{l}\text { Are all the responsible members of the Serbian Army } \\
\text { included in the decision-making process in situations } \\
\text { involving explosive materials? }\end{array}$ & 24 & 22 & 17 \\
\hline Mean values & 38 & 16 & 10 \\
\hline
\end{tabular}


The survey results (Figures 2 to 6 ) clearly show that among 64 respondents there were more members of the Serbian Army who gave positive assessment than those whose assessments were negative:

- that superiors do meet the expectations of their subordinates concerning the decisions made,

- that the subordinates do trust the command system in making quick and efficient decisions,

- that there is responsibility for decisions having been made,

- that operational and functional capabilities of units are maintained when there is potential danger, risk and threat from explosions of explosive materials.

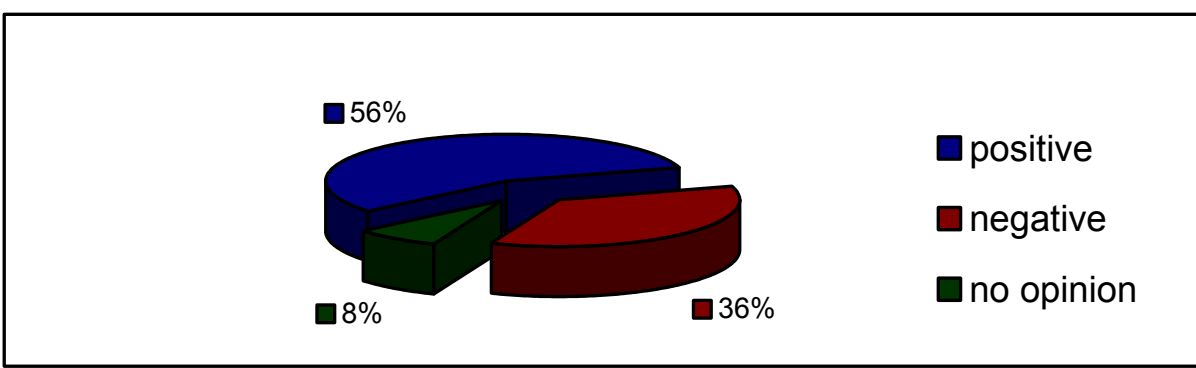

Figure 2 - Assessment of fulfilled expectations from subordinates concerning the decisions made

Puc. 2 - Оценка оправдавшихся ожиданий начальства по поводу принятых решений Слика 2 - Оцена подчињених за донете одлуке надредјених

\section{- $62 \%$}

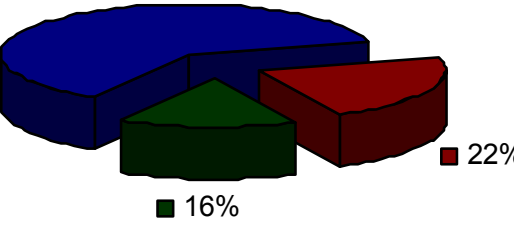

Figure 3 - Assessment of trust in the command system Puc. 3 - Оценка доверия в системе командования Слика 3 - Оцена поверења у систем командовања 


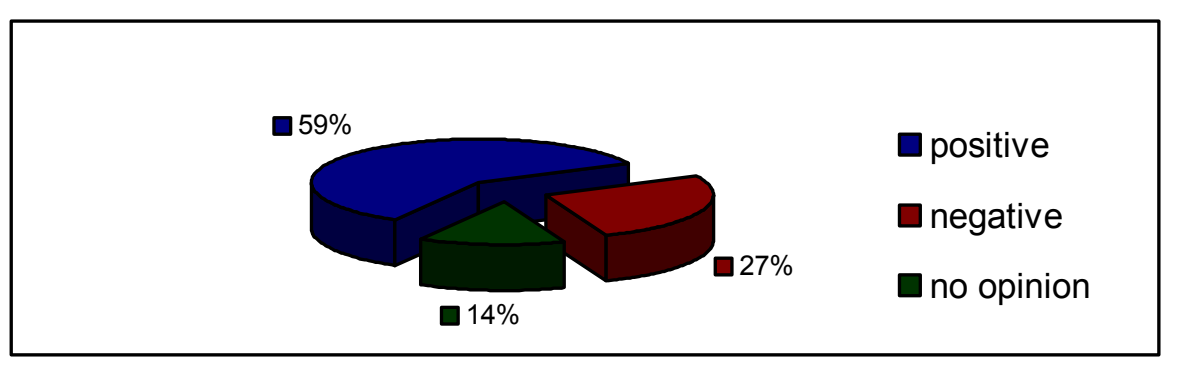

Figure 4-Assessment of rate and efficiency of the already made decisions

Puc. 4 - Оценка скорости и эффрективности принятия решений Слика 4 - Оцена брзине и ефикасности у донетим одлукама

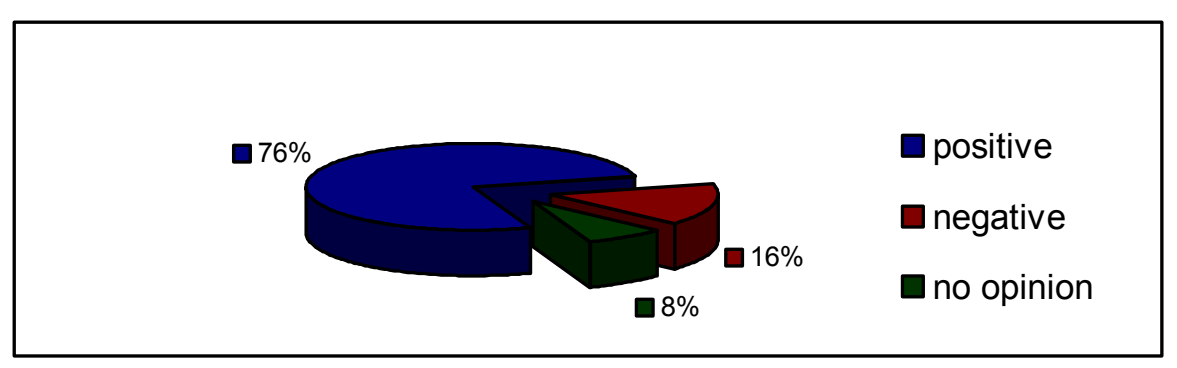

Figure 5 - Assessment of responsibility for the already made decisions

Puc. 5 - Оценка ответственности за принятое решение

Слика 5 - Оцена одговорности за донете одлуке

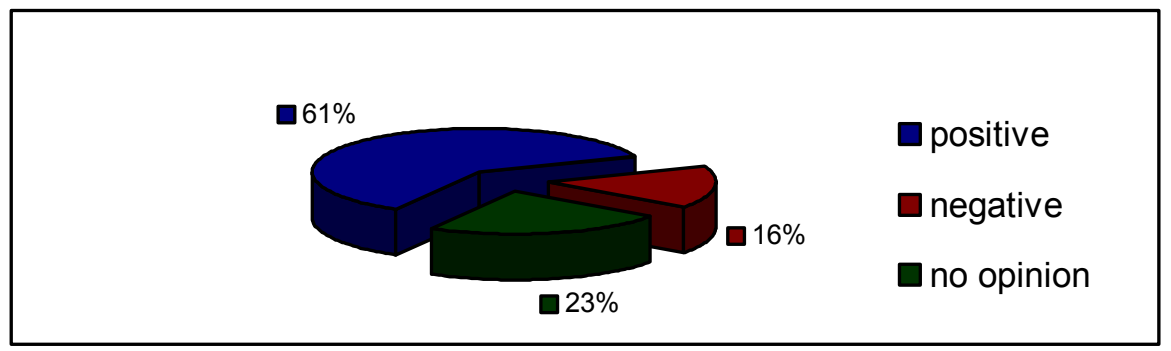

Figure 6 - Assessment of maintaining operational capabilities of units Puc. 6 - Оценка поддержки операционных способностей подразделения Слика 6 - Оцена одржавања оперативних способности јединице 


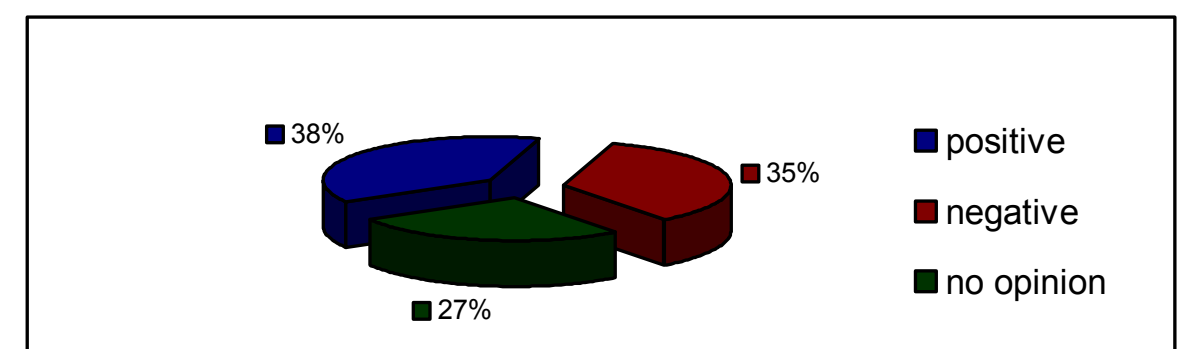

Figure 7 - Assessment of the involvement of all the responsible members of the Serbian Army in decision making

Puc. 7 - Оценка участия всех ответственных лиц - служащих Вооруженных Сил Республики Сербия

Слика 7 - Оцена ангажовања свих одговорних припадника Војске Србије у доношењу одлука

Based on the results of the research, it can be seen that not all responsible members of the Serbian Army are sufficiently involved in important decision making. Finding solutions to safety issues is mainly seen as a responsibility of the highest level of command, which has proven to be insufficient in case of making safe and efficient decisions (Figure 7). This is why, when making important decisions, it is necessary to involve expert teams or independent licensed organizations to the extent determined by the need for safety of people and property and protection from the effects of explosions of explosive materials. When expert team members give different opinions in a particular situation, this can promote a healthy way of advancement and result in finding creative solutions. Expert teams would analyze all the circumstances which could affect the likelihood of the occurence of effects of ordnance explosions. Evaluation of possible adverse events based on the previous knowledge of team members would help analyze events that might cause the effects of ordnance explosion in the future. In order to facilitate their transparency, all the proposed variants should be saved in some form, for instance in the form of a table. Then, decision alternatives could be evaluated which would give the commander a logical framework enabling a greater range of options in the decision-making process, thus reducing the uncertainty in critical situations. This points to the importance of engaging all responsible members of the Serbian Army in analyzing uncertain decisions that are always associated with potential adverse results and consequences. It also points to the selection of one of the proposed alternative variants of events which influences the decision-making process. When more than one person is involved in the assessment of the security situation of the Serbian Army, it is more likely to prevent the occurrence of unforeseen events. 
Sudden effects caused by the effects of explosions of explosive materials, with their size, intensity and abruptness endanger the health and lives of a large number of people, material goods and the environment (Stojanović, 2015, p.136). In situations in which unexpected events unfold in a negative direction, there are frequent occurrences of human anxiety, exhaustion of energy, body paralysis, panic, avoidance and delay of task completion, leading to the lack of concentration and limited possibilities of rational decision making. It is not only situations themselves that cause anxiety, it is also the way of reacting to them, because every decision in every situation of the decision-making process must be in line with the increase of security of people and property, which is constantly confirmed in practice. It can be noticed that in such situations, people who make decisions have big problems possibly leading to hopeless situations because each hazard, risk and threat of possible explosions of explosive materials carries certain amount of fear that prevents people from thinking calmly. Sudden events, therefore, do not occur out of nowhere; there is a process and a cycle of their initiation, generation, development and completion. Listening to the proposals of others and taking into account opinions of expert team members affect the circumstances of unexpected events, and create confidence and calmness among decision-makers before the appearance of adverse events and their culmination.

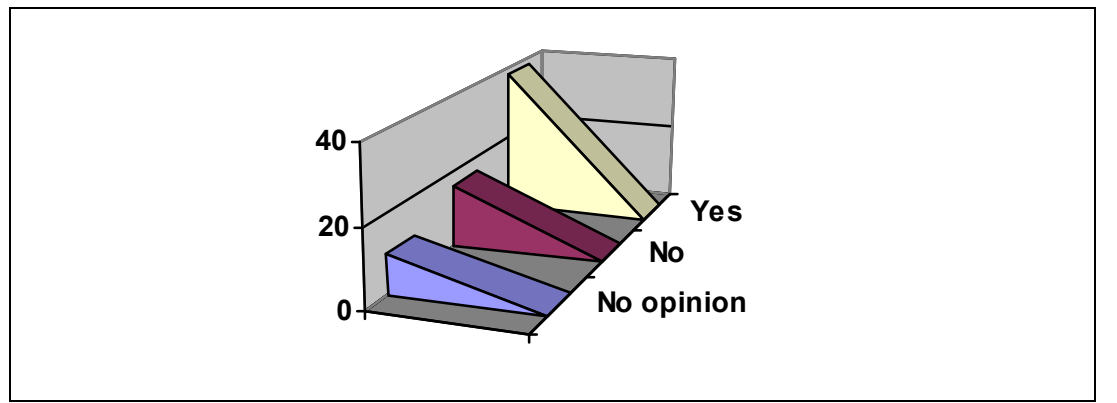

Figure - 8 Result of the mean value

Puc. 8 - Результаты среднего значения

Слика 8 - Резултат средње вредности

Based on the calculated mean value of all the questions in the survey, it can be seen to what extent each question is really present in the workplaces of the Serbian Army members, which leads to the following conclusions (Figure 8): the fact that more respondents responded positively to the survey questions proves that many Serbian Army members agree that optimal decisions have been made concerning their protection from the effects of explosions of explosive materials. A certain number of respondents stated that the issues covered by the given 
questions were not really present in their workplace. This tells us that some of the Serbian Army members do not have a defined opinion concerning this matter. Two conclusions can be drawn from this. One is that the Serbian Army members are not completely satisfied with the current conditions of safety and protection from the effects of explosions in their workplace and their surroundings. The second conclusion is that they do not want to contribute to the development and improvement of the safety situation by not taking a stand and declaring their views concerning this matter.

Consequences are the result of the lack of motivation of the Serbian Army members to improve the current safety situation and do their work in a safe environment. This kind of reaction in practice is known as cognitive dissonance ${ }^{16}$. When it comes to the discrepancy between attitudes and behavior, it often happens that members of the Serbian army themselves say that explosive materials are harmful to people and property, and at the same time they do not sufficiently apply the regulations and rules which determine the methods and procedures of behavior of all persons in places where explosive materials are found. These methods and procedures would, however, help in avoiding unwanted events, or events with negative outcomes.

\section{Conclusion}

Military industry is a very important, responsible, complex and arduous area of activity. It requires superior skills and self -sacrifice from both individuals and the command, exclusively due to the nature of the work they are engaged in. The functioning of this important social organization is entrusted to competent persons who decide the fate of the Serbian Armed Forces under their jurisdiction. In order to avoid surrendering to disorganization in the process of decision making in situations with hazards, risks and threats to people and property from explosions of explosive materials, it is necessary to involve other members of the expert team in making optimal decisions. This confirms that an optimal decision of the Serbian Army members on reducing the effects of the explosion of explosive materials is an integral part of the overall command system, which reduces accidents. Possible accidents, besides causing material damage and consequences to the life and health of

${ }^{16}$ Cognitive disonance is a mental state, often a conflict, in which a person holds an experience of two or more contradictory beliefs or cognitively processes more information. In a healthy individual, it leads to a feeling of mental instability when there is a discrepancy between two or more attitudes or between their behavior and their attitudes (https://www.google.rs/webhp?sourceid=chromeinstant \&ion=1\&espv=2\&ie=UTF8\#q=Temelji+ponasanja+pojedinca). 
people and the environment, would have a negative impact on the public reputation of the Ministry of Defense and the Army of Serbia.

In certain situations, it is very difficult to make optimal decisions since the occurence of the effects of ordnance explosions takes place suddenly, without any warning. This is why this paper is an attempt to, comprehensively and systematically, through the organizational structure of expert teams, propose easier ways of making optimal decisions in order to increase the safety and protection of the Serbian Army members from the effects of ordnance explosions. This process, in which the facts are subjected to scientific analyses, along with an active critical attitude towards the research subject, contributes to the field that has not been sufficiently studied, considering the number of such accidents in the previous period.

\section{References}

Keković, Z., Glišić, G., Komazec, N., 2010. Pristup metodologiji integralnog upravljanja rizikom u organizaciji. Vojno delo, Beograd, 62(3), pp.243-257.

Mijalkovski, M., Đorđević, I., 2010, Rizik - specifičan oblik ugrožavanja bezbednosti, Vojno delo, 62(1), pp.282-306.

Pravilo samohodna haubica $122 \mathrm{~mm} 2 \mathrm{~S} 1$ Gvozdika, 1981. Generalštab Vojske SFRJ, Beograd.

Službeni glasnik Republike Srbije, 88/2009, Zakon o Vojsci Srbije, Beograd, JP „Službeni glasnik”.

Službeni vojni list, 20/2014, Pravilnik o bezbednosti i zdravlju na radu u Ministarstvu odbrane i Vojsci Srbije, Beograd, Ministarstvo odbrane Republike Srbije.

Stojanović, D., 2013. Zaštita lica i imovine od efekata eksplozije i eksplozivnih materija, Beograd, Kriminalističko-policijska akademija, specijalistički rad, pp.1-109.

Stojanović, D., 2015. Procena bezbednosne ugroženosti ljudi i imovine od efekata eksplozije eksplozivnih sredstava u Vojsci Srbije. Vojnotehnički glasnik/Military Technical Courier, Beograd, 63(4), pp.135-165, doi:10.5937/vojtehg63-7245.

Stojanović, D., Stojilković, P., 2016. Ublažavanje bezbednosne ugroženosti ljudi i imovine od efekata eksplozije eksplozivnih sredstava u Vojsci Srbije. Vojnotehnički glasnik/Military Technical Courier, Beograd, 64(4), pp.1065-1082, doi:10.5937/vojtehg64-8399.

Intuitivno odlučivanje, [Internet], Available from: https://prezi.com/llc4qg94zrzj/ intuitivno-odlucivanje/, Accessed: 2016 Feb 3.

Temelji ponašanja pojedinca, [Internet], Available from: https://www.google.rs/webhp?sourceid=chrome-instant\&ion=1\&espv=2\&ie=UTF8\#q=Temelji+ponasanja+pojedinca, Accessed: 2016 Mar 29. 
Verovatnoća, [Internet], Available from: http://starisajt.elfak.ni.ac.rs/phptest/ new/html/Studije/predavanja-literatura/matematika-odabranapoglavlja/verovatnoca.pdf, Accessed: 2016 Jan 20.

\section{МЕТОДЫ ОПТИМАЛЬНЫХ РЕШЕНИЙ ПО СМЯГЧЕНИЮ ПОСЛЕДСТВИЙ ВЗРЫВА ВЗРЫВЧАТЫХ СРЕДСТВ, ПРИНИМАЕМЫХ СЛУЖАЩИМИ ВООРУЖЕННЫХ СИЛ РЕСПУБЛИКИ СЕРБИЯ}

Деян С. Стоянович ${ }^{a}$, Петар Л. Стоилькович

а Вооруженные силы РС, 4-ая пехотная бригада, г. Вранье, Республика Сербия

б Институт охраны труда и противопожарной безопасности, ООО «ВИП Центр» г. Лесковац, Республика Сербия

ОБЛАСТЬ: охрана окружающей среды и критический менеджмент ВИД СТАТЬИ: профессиональная статья ЯЗЫК СТАТЬИ: английский

Резюме:

Служащие Вооруженных Сил Республики Сербия, принимая оптимальные решения непосредственно влияют на возможность предотвращения различных фрорм опасных происшествий, таких как взрыв взрывчатых средств, который может повлечь за собой катастрофические последствия. Если иметь в виду, что основной характеристикой взрывчатых веществ является быстрое самораспространяющееся химическое превращение (взрыв) $c$ выделением большого количества тепла и газообразных продуктов, под воздействием которых может быть уничтожен весь живой мир, своевременное и правильно принятое решение представляет основание для благовременного устранения всех возможных источников угрозы безопасности для людей и их имущества от взрыва взрывчатых средств. Так как подобные происшествия наступают неожиданно и непредвиденно, или же наступают постепенно, но незаметно, в дальнейшем принимая угрожаюшую фрорму. $B$ связи $C$ вышеперечисленными видами опасности, рисков и угроз служащие Вооруженных Сил Республики Сербия при принятии оптимальных решений по снижению последствий взрывов взрывчатых средств должны прилагать все усилия для предотвращения любой фрормы неконтролируемого явления, которое может привести к взрыву.

Ключевые слова: оптимальное решение, взрывчатые средства, взрыв. 
Дејан С. Стојановић ${ }^{\mathrm{a}}$, Петар Љ. Стојилковић ${ }^{6}$

а Војска Србије, 4. бригада КоВ, Врање, Република Србија

б Институт за безбедност и здравље на раду и заштиту од пожара ВИП Центар д.о.о. Лесковац, Република Србија

ОБЛАСТ: заштита животне средине и кризни менаџмент ВРСТА ЧЛАНКА: стручни чланак ЈЕЗИК ЧЛАНКА: енгЛесКИ

\section{Сажетак:}

Припадници Војске Србије, доношењем оптималних решења, превентивно делују на сваки облик појављивања нежељених догађаја приликом експлозија експлозивних средстава са катастрофалним исходом. Ако се зна да је основна карактеристика свих експлозивних средстава ослобађање велике количине енергије хемијским разлагањем, која је способна да изврши механички рад на околину, уништавајући сав живи свет, онда правовремена решења представљају основу за благовремено отклањање свих могућих извора угрожавања људи и имовине од експлозије експлозивних средстава. У оваквим околностима негативни догађаји наступају одједном и изненада или почињу лагано и даљим током попримају све израженије облике. Имајући у виду наведене облике опасности, ризика и претњи, припадници Војске Србије приликом доношења оптималних решења за смањење ефеката експлозије експлозивних средстава, морају настојати да спрече сваки облик неконтролисаног појављивања овог ефекта.

Кључне речи: оптимална одлука, експлозивна средства, експлозија.

Paper received on / Дата получения работы / Датум пријема чланка: 16. 03. 2016. Manuscript corrections submitted on / Дата получения исправленной версии работы / Датум достављања исправки рукописа: 26. 05. 2016.

Paper accepted for publishing on / Дата окончательного согласования работы / Датум коначног прихватања чланка за објављивање: 28. 05. 2016.

( 2017 The Authors. Published by Vojnotehnički glasnik / Military Technical Courier (www.vtg.mod.gov.rs, втг.мо.упр.срб). This article is an open access article distributed under the terms and conditions of the Creative Commons Attribution license (http://creativecommons.org/licenses/by/3.0/rs/).

() 2017 Авторы. Опубликовано в «Военно-технический вестник / Vojnotehnički glasnik / Military Technical Courier» (www.vtg.mod.gov.rs, втг.мо.упр.срб). Данная статья в открытом доступе и распространяется в соответствии с лицензией «Creative Commons» (http://creativecommons.org/licenses/by/3.0/rs/).

(C) 2017 Аутори. Објавио Војнотехнички гласник / Vojnotehnički glasnik / Military Technical Courier (www.vtg.mod.gov.rs, втг.мо.упр.срб). Ово је чланак отвореног приступа и дистрибуира се у складу са Creative Commons licencom (http://creativecommons.org/licenses/by/3.0/rs/). 